\title{
FORMULASI HUKUM ISLAM; SUATU KAJIAN IMPLIKASI LAFAZ WADIH DAN MUBHAM \\ Oleh
}

Fatahuddin Aziz Siregar

Dekan Fakultas Syariah dan Ilmu Hukum IAIN Padangsidimpuan email : fatahuddinaziz@iain-padangsidimpuan.ac.id

\begin{abstract}
Abstrac
Strengthening the understanding of the verses of the Qur'anic verses and the Sunnah feels so important that the legal products produced reflect the true will of the Shari'a, not based on the power of logic alone. There is Lafaz wadih, namely lafaz which is presented in a clear form consisting of various levels, namely zahir, nas, mufassar, and muhkam. Lafaz Zahir and Nas are lafaz that are bright enough but contain several possible meanings, so it needs to be understood by looking at other factors. While mufassar and muhkam do not need factors outside the text to be accurately understood. there is a vague lafaz (mubham), so to just understand it requires a factor outside it. For categories that are fairly clear this does not need to be explored further, it is enough to do it based on the clarity of its meaning. As for what is vaguely presented, an in-depth study is needed to arrive at the right understanding. However, if it is too vague, a mujtahid does not need to force himself to look for food and condemn the law of the lafaz. And indeed there is no need to gain understanding from this type of text, because in general it is not part of the practical life of the law.
\end{abstract}

Kata Kunci; Formulasi, Hukum, Islam, Wadih, dan Mubham

\section{A. Pendahuluan}

Memahami lafaz nas untuk melakukan formulasi hukum Islam meniscayakan pemahaman yang akurat. Akurasi yang dimaksud disini tentu saja sebatas upaya optimal yang mungkin dilakukan lewat interpretasi terhadap teks-teks suci. Dalam kaitan ini ulama merumuskan seperangkat alat untuk mendekatkan peminat studi Islam, khususnya berkenaan dengan hukum, pada pemahaman yang benar menuju realisasinya yang tepat. Sistematisasi pemahaman terhadap hukum Islam dibuat melaui sebuah ilmu yang disebut Ushul Fiqh. Pembahasan-pembahasannya dirinci sedemikian rupa sesuai kepentingannya dalam menangkap pesan-pesan Ilahi terutama nas al-Quran. Masing-masing ahli usul kemudian membuat sitematika semdiri dalam kitabnya ketika mengkaji permasalahan usuli. Wahbah az-Zuhaili misalnya menempatkan pembahasan al-ahkam asy-syar'iyyah pada bab pertama, disusul pembahasan tentang metode penetapan hukum dari nas-nas syar'iyyah yang juga dikenal dengan metode literal pada bab kedua serta pembahasan-pembahasan lain pada babbab berikutnya. ${ }^{1}$ Bab kedua dibagi lagi pada beberapa fasal yaitu kaifiyyah istinbat al-ahkam 
min an-nusus dan huruf al-ma'ani. Fasal pertama seterusnya dibagi pada empat taqsim yaitu taqsim berdasaarkan penetapan lafaz terhadap makna, berdasarkan pemakaian lafaz terhadap makna. Berdasarkan dalalah lafaz terhadap makna dan pembagian lafaz berdasarkan metode penunjukannya terhadap makna. Taqsim (pembagian) ketiga (metode penetapan hukum berdasarkan dalalah lafaz) akan dijadikan pembahasan pada bab ini untuk kemudian pada bab v tesis ini dijadikan sebagai pisau analisis.Berdasarkan dalalahnya terhadap makna, lafaz terbagi dua, wadih ad-dalalah dan khafi ad-dalalah (mubham).

\section{B. Kajian Implikasi Lafaz Wadih dalam Formulasi Hukum Islam}

Wadih ad-dalalah ialah lafaz yang maknanya langsung dimengerti dengan melihat redaksinya tanpa tergantung pada faktor di luarnya. ${ }^{2}$ Adapun mubham adalah lafaz yang maknanya tersamar, ketersamarannya kadangkala karena redaksinya sendiri dan bisa juga karena faktor eksternal. Memahami maknanya hanya mungkin dengan melihat dan membandingkan dengan lafaz lain. ${ }^{3}$ Kedua bentuk lafaz ini mempunyai tingkatan-tingkatan yang antara masing-masing tingkatannya berbeda dan disusun secara hirarkis. Suatu lafaz wadih lebih jelas dibanding lafaz wadih lainnya, dan suatu lafaz mubham lebih tersamar maknanya dibandingkan lafaz mubham yang lain.

Tingkatan wadih ada empat, yakni zahir, nas, mufassar, dan muhkam. Keempat macam lafaz ini saling berbeda derajat kejelasannya, dan urutan penyebutannya sekaligus merupakan urutan tingkatan kejelasannya (yang disebut belakangan lebih jelas dibanding yang di depannya). Berarti yang lebih tinggi adalah muhkam disusul mufassar, kemudian nas dan terkhir zahir. Perbedaan ini disebabkan oleh derajat kemungkinan mengalihkan lafaz dari maknanya, kemungkinan menerima naskh faktor-faktor lainnya.

Sementara tingkatan mubham juga ada empat, yaitu khafi, musykil, mujmal dan mutasyabih. Keempat lafaz ini juga berbeda derajat ketidakjelasannya. Yang paling sedikit ketersamarannya adalah khafi, kemudian musykil, disusul oleh mujmal dan terakhir mutasyabih. Keempat jenis mubham ini merupakan lawan dari empat jenis yang pertama. ${ }^{4}$ Khafi sebanding dengan zahir, musykil setara dengan nas, mujmal dengan mufassar dengan mutasyabih dengan muhkam.

Berlainan dengan dua kelompok tersebut, pengertian yang berbeda dikemukakan oleh sejumlah ahli usul lain. Abdul Wahab Khallaf misalnya mendefinisikan zahir dengan lafaz yang menunjukkan arti yang diinginkan lewat sigatnya tanpa tergantung pada faktor diluarnya, dan dari arah pembicaraannya (siyaq), maksud yang diinginkan tersebut bukanlah 
makna asal, dan zahir ini menerima ta' wil. ${ }^{5}$ Beberapa Ahli usul lain yang sependapat dengan ini adalah Zakiyuddin Sya'ban, ${ }^{6}$ Syaikh al-Khudary, ${ }^{7}$ Muhammad Abu Zahrah, ${ }^{8}$ Ali Hasaballah. ${ }^{9}$ Demikian juga dengan Muhammad Adib Solih, setelah memaparkan definisidefinisi yang diajukan oleh sejumlah pakar usul beliau kemudian membuat semacam rangkuman dan merumuskan sebuag definisi yang menurutnya bersifat komprehensif dan sesuai dengan maksud zahir tersebut ( gard), yaitu lafaz yang maknanya ditunjukkan langsung oleh redaksi kalimatnya, tanpa tergantung pada qarinah di luarnya, dan membuka kemungkinan bagi adanya takhsis ta'wil, bahkan terkadang ia menerima naskh. ${ }^{10}$ Contoh yang sering dikemukakan dalam menjelaskan lafaz sarih ini adalah ayat berikut: ${ }^{11}$

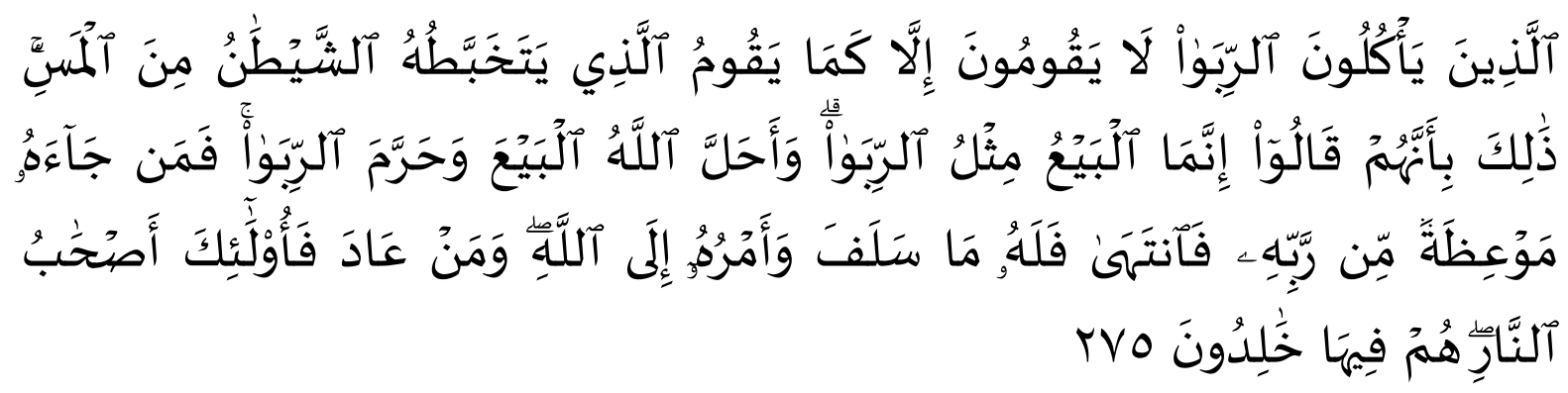

Artinya:

"Orang-orang yang makan (mengambil) riba tidak dapat berdiri melainkan seperti berdirinya orang yang kemasukan syaitan lantaran (tekanan) penyakit gila. Keadaan mereka yang demikian itu, adalah disebabkan mereka berkata (berpendapat), sesungguhnya jual beli itu sama dengan riba, padahal Allah telah menghalalkan jual beli dan mengharamkan riba. Orang-orang yang telah sampai kepadanya larangan dari Tuhannya, lalu terus berhenti (dari mengambil riba), maka baginya apa yang telah diambilnya dahulu (sebelum datang larangan); dan urusannya (terserah) kepada Allah. Orang yang kembali (mengambil riba), maka orang itu adalah penghuni-penghuni neraka; mereka kekal di dalamnya" \{Qs. Al-Baqarah/2:275 \}

Sababun nuzul ayat ini bagitu populer di kalangan umat Islam, yautu diturunkan untuk membantaj komunitas Yahudi yang menganggap sama praktek jual beli dan perbuatan riba. Secara zahir ayat ini menyatakan halalnya jual bali dan haramnya riba dengan redaksi kalimatnya sendiri dan tidak memerlukan penjelasan dari luar dirinya. Masing-masing kata

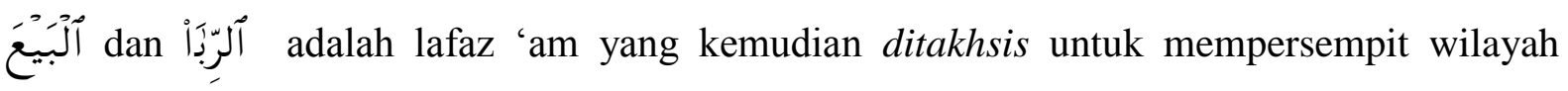
cakupannya menjadi terbatas hanya pada beberapa afrad saja. Jadi kahalalan jual beli mesti dipahami sebatas yang memenuhi ketentuan syara'.

a. Nas

Secara etimologi nas berarti mengangkat sesuatu sehingga menjadi tampak atau terang. ${ }^{12}$ Beberapa contoh penggunaan dalam kalimat. Sebelum menjelaskan makna terminologisnya, perlu dikemukakan bahwa nas yang dimaksud di sini bukanlah 


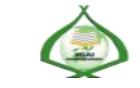

Volume 4 Nomor 2 Edisi Juli-Desember 2018

sebagaimana pemakaian yang lebih lazim dikenal, yaitu berupa dalil syara' seperti ayat al-Quran atau matan hadis dan bukan pula dalam arti fiqh mazhab yaitu qaul (pendapat) seorang mazhab yang dijadikan dasar untuk melakukan ijtihad bagi pengikutnya, tapi tentu saja dalam koridor pembahasan lafaz dari segi kejelasan artinya.

Adapun pengertian terminologisnya dapat dipaparkan dengan mengutip sejumlah definisi yang diajukan oleh beberapa ahli usul terutama yang berasal dari mazhab Hanafi. Ad-Dabusi secara singkatmengartikannya dengan lafaz yang kejelasannya melebihi zahir. ${ }^{13}$ Definisi ini kelihatannya kurang komprehensif sebab memberikan penjelasan lebih lanjut tentang kelebihan yang dimaksud. Agaknya definisi al Bazdawi lebih informatif. Beliau mendefinisikan nas sebagai lafaz yang lebih jelas dibanding zahir, dimana kejelasan itu tidak langsung tersurat pada sigat, akan tetapi maknanya diberikan oleh mutakallim secara tersirat. ${ }^{14}$ As-Sarkhasi kemudian merumuskan definisi yang sedikit lebih jelas dengan mengatakan bahwa nas adalah lafaz yang lebih jelas (dibanding zahir) yang kelebihan tersebut ditunjukkan oleh sebuah qarinah (pertalian maksud) yang berhubungan dengan lafaz dari mutakallim (Allah) dimana pada lafaz secara zahir sesungguhnya tidak ada yang mengharuskan (pemahaman yang lebih terang tersebut) tanpa adanya qarinah. ${ }^{15}$

Dari beberapa definisi yang dimunclkan di atas terlihat bahwa inti pokok dari pendefinisian nas adalah adanya kelebihan kejelasan makna apabila dicoba bandingkan dengan lafaz zahir. Dan kelebihan dimaksud berkaitan dengan konteks lafaznya, tidak tertera langsung pada kata-kata yang digunakan dalam redaksi kalimatnya.

b. Mufassar

Mufassar adalah lafaz yang menunjukkan pada sebuah ketentuan hokum secara jelas tanpa membuka peluan sama sekali untuk dita'wil, ditakhsis, akan tetapi terkadang menerima naskh pada masa risalah. ${ }^{16}$

As-Sarkhasi juga member definisi yang sama. Persisinya beliau menyatakan bahwa mufassar adalah nama bagi sesuatu yang terbuka yeng terkenal secara terbuka sebagai sebuah bentuk tertentu yang tidak mengandung kemungkinan untuk dita' wil. ${ }^{17}$

Dari pengertian di atas dapat disimpulkan bahwa hakekat lafaz mufassar adalah kejelasan dalallahnya, yang tidak memerlukan sebuah qarinah dan tidak bisa dita'wil. Dengan demikian posisi mufassar berada diatas zahir dan nas, karena kedua bentuk lafaz tersebut masih menerima ta'wil dan takhsis.

Contoh ayat mufassar: ${ }^{18}$ 


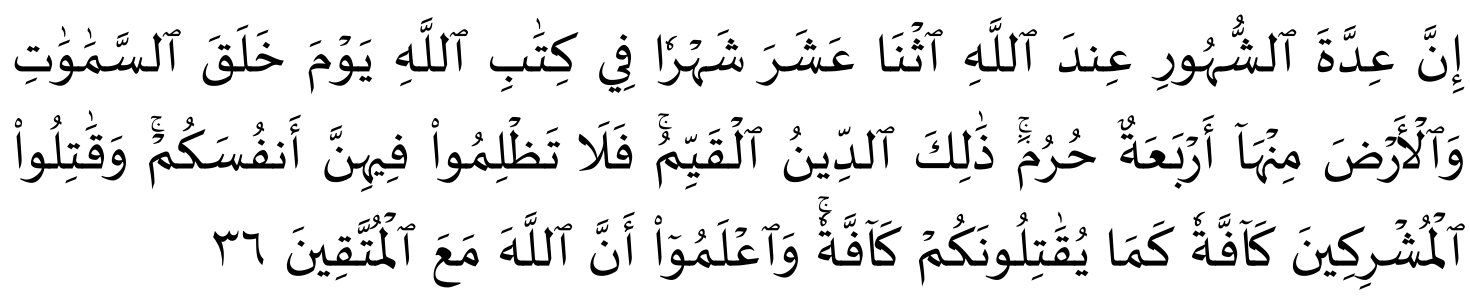

Artinya:

"Sesungguhnya bilangan bulan pada sisi Allah adalah dua belas bulan, dalam ketetapan Allah di waktu Dia menciptakan langit dan bumi, di antaranya empat bulan haram. Itulah (ketetapan) agama yang lurus, maka janganlah kamu menganiaya diri kamu dalam bulan yang empat itu, dan perangilah kaum musyrikin itu semuanya sebagaimana merekapun memerangi kamu semuanya, dan ketahuilah bahwasanya Allah beserta orang-orang yang bertakwa" $\{$ Qs. At-Taubah/9:36 $\}$

Lafaz لَمْشُرِكِيَتَ sepintas memerlukan takhsis, bisa saja dipahami bahwa yang dimaksud sebagian tertentu orang musyrik sedang sebagian lainnya tidak termasuk dalam cakupan lafaz itu. Namun ketika dirangkaikan dengan lafaz maksudnya menjadi jelas yaitu semua orang musyrik, sehingga gugurlah segala kemungkinan mentakhsisnya hanya pada individu atau sekelompok orang musyrik tertentu. Dengan demikian tidak satupun yang terlepas dari kewajiban memenuhi perintah tersebut.

Begitu juga halnya pemahaman terhadap ayat berikut: ${ }^{19}$

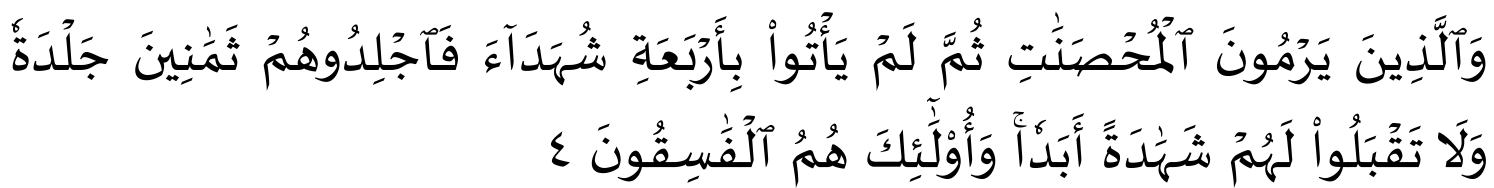

Artinya:

"Dan orang-orang yang menuduh wanita-wanita yang baik-baik (berbuat zina) dan mereka tidak mendatangkan empat orang saksi, maka deralah mereka (yang menuduh itu) delapan puluh kali dera, dan janganlah kamu terima kesaksian mereka buat selamalamanya. Dan mereka itulah orang-orang yang fasik." \{Qs. An-Nur/24:4

Lafaz ثما نين pada ayat tersebut berbentuk bilangan merupakan sesuatu yang pasti dan terukur secara eksak, tidak akan mengalami pengurangan dan penambahan.

Termasuk juga pada kategori mufassar, lafaz yang berbentuk umu, kemudian diiringi oleh lafaz yang menegaskan adanya takhsis. Misalnya: ${ }^{20}$

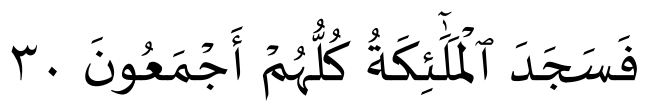

Artinya: 


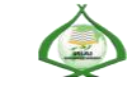

Volume 4 Nomor 2 Edisi Juli-Desember 2018

"Maka bersujudlah para malaikat itu semuanya bersama-sama"

Lafaz al-malaikat sebenarnya berbentuk am, dan mungkin saja ditakhsis sehingga terbatas pada sebagian besar malaikat saja misalnya. Pembicaraan takhsis menjadi tidak pada tempatnya lagi ketika diiringi oleh lafaz Setelah itu masih didapati kemungkinan $t a$ 'wil. Barangkali sujudnya malaikat tidak dilakukan berbarengan. Lafaz membuat pemahaman kita jadi benar, yaitu semua malaikat bersujud secara bersamaan.

Dijelaskan bahwa termasuk juga pada mufassar, sigat yang berbentuk mujmal yang mendapat penafsiran langsung dari syari' dan membuatnya setara dengan mufassar. Contohnya, lafaz-lafaz seperti as-sala,az-zakat dan al-hajj adalah lafaz-lafaz mujmal yang masing-masing memiliki makna lugawi. Ayat-ayat yang memuat perintah yang berkaitan dengan lafaz-lafaz itu diberi penafsiran oleh Nabi melaui sabdanya. Berubahlah status lafaz ini menjadi mufassar.

c. Muhkam

Muhkam menurut Muhammad adib Salih adalah lafaz yang menunjukkan maknanya sendiri secara jelas dan pasti, serta tidak sedikitpun mengandung kemungkinan untuk dita'wil, ditakhsis dan dinaskh baik pada masa rasul, apalagi setelah wafatnya. ${ }^{21}$

و الله بكلل ثيء عليم:Contoh yang beliau kemukakan adalah

Pengertia dari ayat tersebut sungguh telah terang benderang menurut pencapaian rasio, yaitu bahwa sifat pengetahuan allah yang meliputi segala sesuatu berlaku abadi, tidak mungkin dugugurkan.

Defenisi yang lebih detail dikemukakan oleh Abdul Wahhab Khallaf sebagai berikut: Muhkam adalah lafaz yang menunjukkan kepada maknanya, yang tidak menerima pembatalan dan penggantian dengan sendirinya secara jelas, dan sama sekali tidak mengandung tak'wil, yaitu tidak menghendaki arti lain yang bukan ari zahirnya. Karena ia dijelaskan dan ditafsiri dengan penafsiran yang tidak membuka kemungkinan pentak'wilan baginya. Juga tidak menerima naskh pada masa kerasulan dan pada masa fatrah tanzil (kekosongan waktu) dan tidak juga sesudahnya. Ini karena hukum yang dapat digali dari lafaz 


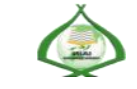

Volume 4 Nomor 2 Edisi Juli-Desember 2018

tersebut adakalanya berupa hukum asasi seperti kaidah-kaidah pokok agama yang tidak menerima penggantian. ${ }^{22}$

Menomentari demikian ternegasinya muhkam dari tak'wil dan naskh as-Sarkhasi menyatakan bahwa karena keadaannya yang begitu kokoh allah Swt kemudian menyebut ayat-ayat muhkam sebagai umm al-kitab, ${ }^{23}$ yaitu asal yang menjadi tempat rujukan sebagaimana eksistensi ibu bagi seorang anak.

Dari paparan diatas dapat dikemukakan bahwa seperti halnya mufassar yang tidak menerima tak'wil dan takhsis maka muhkam yang berada di posisi paling tinggi juga memiliki ciri yang sama. Tidak menerima tak'wil yang menghendaki makna lain jika redaksinya berbentuk khusus, tidak menerima takhsis yang menghendaki makna khusus jika redaksinya berbentuk umum, karena muhkam telah bersifat mufassal dan mufassar yang sama sekali tidak dimungkinkan adanya pmehaman lain. Lebih dari itu muhkam bahkan tidak menerima naskh yang masih bisa terjadi pada mufassar. Kepastian, absolut dan langgengnya muhkam terjadi sejak masa rasul, dengan demikian menurut qiyas aula masa setelah itu mesti lebih tidak punya peluang untuk menghapuskannya.

Memiliki pada faktor yang menyebabkan sebuah lafaz bernilai absolut dan konstan, muhkam terbagi menjadi dua macam, yaitu:

1. Muhkam lizatihi, yaitu muhkam yang disebabkan oleh faktor internal yang berasal dari diri lafaz sendiri secara mandiri. Menurut akal tidak terdapat kemungkinan bagi pemalingan makna lafaz tersebut, misalnya ayat-ayat yang menjelaskan adanya sang pencipta, ayat-ayat yang menerangkan sifat-sifat allah dan ayat-ayat yang mendiskripsikan terjadinya alam semesta. ${ }^{24}$

2. Muhkam ligairihi, ialah lafaz yang menjadi muhkam karena faktor eksternal dari luar dirinya, yaitu karena telah terputusnya wahyu. Muhkam jenis ini mencakup tingkatan keempat tingkat wadih ad-dilalah (zahir, nas, mufassar, dan muhkam). Zahir dan mufassar akan mendapatkan status muhkam sepanjang tidak telah dinaskh.

\section{Kajian Implikasi Lafaz Mubham dalam Formulasi Hukum Islam}

1. Mubham

a. Khafi

Kalau pada wadih, zahir merupakan jenis yang paling rendah tingkat kejelasannya, makna khafi berada pada posisi yang sebanding, yaitu jenis yang paling rendah tingkat ketersamarannya. 
Khafi secara lughah merupakan derivasi dari khafi yaitu tidak jelas satr dan kitman. Adapun secara terminologis, ulama memformulasikannya dalam pengertian yang beraneka ragam yang satu sama lain saling berddekatan (hanya perbedaan redaksional), dan tidak sampai mengakibatkan pengertian yang berbeda. ${ }^{25}$

Ad-Dabusi dalam kitabnya Taqwimal-Adillah mendefinisikan khafi sebagai lafaz yang maknanya tersamar karena adanya sebuah dalil yang bukan berbentuk lafaz yang berimplikasi pada semakin jauhnya pemahaman, dan pemahaman tersebut hanya akan bisa dicapai lewat sebuah upaya pencarian yang serius. ${ }^{26}$ Senada dengan itu al-Bazdawi member definisi khafi sebagai sesuatu yang bermakna ganda dan maksudnya tidak jelas, dimana ketidakjelasannya diakibatkan oleh halangan yang bukan berupa sigat dan maksud tersebut tidak akan mungkin decapai kecuali dengan melakukan upaya serius.

As-Sarkhasi kemudian menggabungkan kedua definisi di atas dengan memformulasikan khafi sebagai nama bagi sesuatu yang tersamar maknanya dan tersembunyi maksudnya karena adanya hambatan tertentu yang bukan terdapat pada sigat dan menghalangi untuk menangkap maksud dari sesuatu (lafaz) tersebut. Pencapaian pemahaman terhadap maknanya mesti dengan usaha pencarian maksimal. ${ }^{27}$

Definisi yang komprehensif dan jelas dapat kita temui pada Tafsir an-Nusus. Muhammad adib Saleh dalam kitab tersebut setelah mempermaklumkan bentuk-bentuk formulasi yang ditawarkan oleh sejumlah ulama, kemudian member definisi khafi sebagai lafaz yang sesungguhnya zahir dalam penunjukannya pada makna tertentu, namun kemudian ada penghalang yang dating dari luar sigatnya yang menjadikan penerapan makna pada sebagian satuannya meragukan dan terhalang, keraguan dan halangan itu hanya mungkin disingkirkan dengan upaya yang menuntut keseriusan dan ijtihad penuh. Memiliki pada sebagian satuannya yang tersamar ini, lafaz tersebut dinamai khafi. ${ }^{28}$

b. Musykil

Musykil adalah lafaz yang menunjukannya terhadap maknanya tersamar karena zat (lafaz) nya sendiri. Eliminasi ketersamarannya dapat dilakukan dengan pembahasan mendalam dan perenungan, seperti kalau sebuah lafaz mencakp banyak makna haqiqi dan majazi. Memastikan salah satu diantaranya haruslah melalui pembahasan mendalam.

Pendapatnya yang agak ekstrim menyatakan bahwa lafaz Musykil itu dari segi sigatnya sendiri tidak menunjukkan maksud tertentu, oleh karenanya diperlukan 
qarinah dari luar yang menjelaskan apa yang dimaksud oleh lafaz tersebut. ${ }^{29}$ Sumber kesamaran itu berasal dari lafaz itu sendiri. Adakalanya karena lafaz itu digunakan untuk arti yang banyak secara penggunaan yang sebenarnya sehingga tidak dapat dipahami artinya dari semata-mata hanya melihat kepada lafaz itu. Mungkin pula ketidakjelasan lafaz itu karena ada pertentangan antara apa yang dipahami dari suatu nas dengan apa yang dipahami dari nas lain.

Untuk kasus pertama dapat diambil contoh berikut: ${ }^{30}$

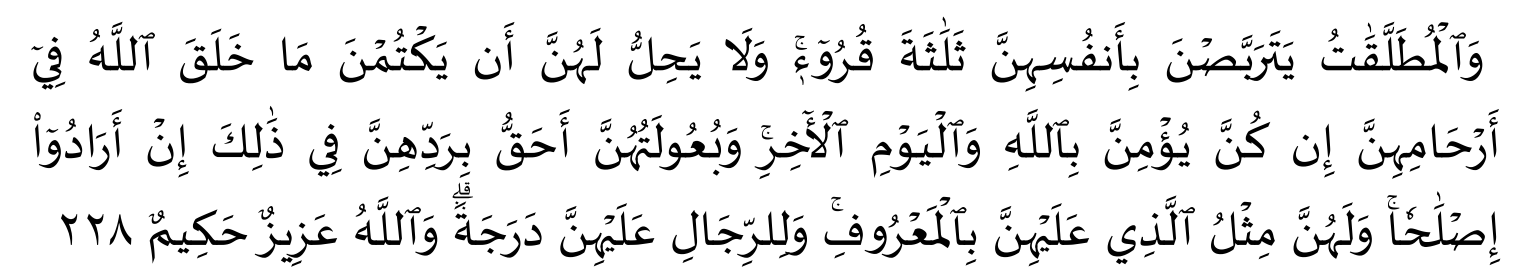
Artinya"

"Wanita-wanita yang ditalak handaklah menahan diri (menunggu) tiga kali quru'. Tidak boleh mereka menyembunyikan apa yang diciptakan Allah dalam rahimnya, jika mereka beriman kepada Allah dan hari akhirat. Dan suami-suaminya berhak merujukinya dalam masa menanti itu, jika mereka (para suami) menghendaki ishlah. Dan para wanita mempunyai hak yang seimbang dengan kewajibannya menurut cara yang máruf. Akan tetapi para suami, mempunyai satu tingkatan kelebihan daripada isterinya. Dan Allah Maha Perkasa lagi Maha Bijaksana”. \{Qs. Al-Baqarah/2:228\}

Secara kebahasaan, lafaz quru' bermakna ganda, yaitu suci dan haid. Makna ganda ini berimplikasi pada perbedaan istinbat hukum, karenanya lafaz tersebut termasuk pada lafaz Musykil. Untuk memastikan maksud sebenarnya diperlukan qarinah yang berasal dari luar nas. Dalam hal ini ulama Hanafiah misalnya, menafsirkan quru' sebagai haid. Argumentasi yang mereka kedepankan adalah bahwa fungsi 'iddah tidak lain dari meyakinkan seorang janda terbebas dari kehamilan. Haid menjadi yang paling memperlihatkan keadaan tersebut. ${ }^{31}$

Sedangkan ulama Syafi'iyah menafsirkan quru' sebagai suci. Mereka mendasarkan pendapat pada firman Allah dalam ayat yang lain فطقو هن لعد تهن artinya pada masa iddah mereka. Padahal talaq yang disyariatkan tentu saja ketika isteri sedang dalam keadaan suci.

Terlepas dari kontroversi di atas, penghilangan kesamaran lafaz tersebut merupakan wacana ijtihad, sebuah upaya pencarian makna berkaitan dengan faktor-faktordi luar nas.

Adapun lafaz musykil yang mengalami benturan makna dengan ayat lain dapat dikemukakan contoh berikut. ${ }^{32}$ 


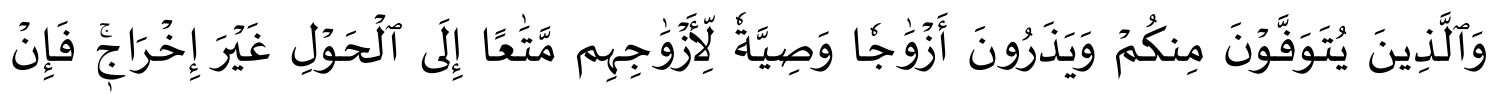

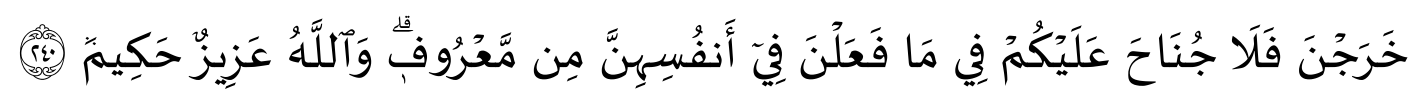

Artinya:

"Dan orang-orang yang akan meninggal dunia di antara kamu dan meninggalkan isteri, hendaklah berwasiat untuk isteri-isterinya, (yaitu) diberi nafkah hingga setahun lamanya dan tidak disuruh pindah (dari rumahnya). Akan tetapi jika mereka pindah (sendiri), maka tidak ada dosa bagimu (wali atau waris dari yang meninggal) membiarkan mereka berbuat yang ma'ruf terhadap diri mereka. Dan Allah Maha Perkasa lagi Maha Bijaksana”. \{Qs. Al-Baqarah/2:240\}

Pemahaman zahir ayat ini berbenturan dengan makna zahir yang tersimak pada ayat 234 surat al-Baqarah. ${ }^{33}$

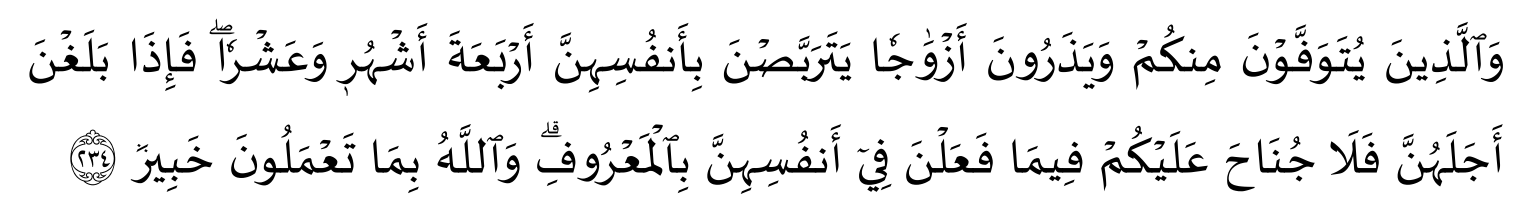

Artinya:

"Orang-orang yang meninggal dunia di antaramu dengan meninggalkan isteri-isteri (hendaklah para isteri itu) menangguhkan dirinya (ber'iddah) empat bulan sepuluh hari. Kemudian apabila telah habis 'iddahnya, maka tiada dosa bagimu (para wali) membiarkan mereka berbuat terhadap diri mereka menurut yang patut. Allah mengetahui apa yang kamu perbuat". \{Qs. Al-Baqarah/2:234\}

Merujuk pada ayat pertama, isteri berhak untuk bersenang-senang di rumah almarhum bekas suaminya selama setahun. Dengan demikian seolah-olah dia tidak boleh menikah sepanjang interval waktu tersebut. Sementara itu ayat kedua secara tegas menyatakan bahwa masa iddah interi yang ditinggal mati suaminya adalah empat bulan sepuluh hari. Berarti terjadi pertentangan antara dua ayat. Untuk keluar dari kontradiksi ini diperlukan pemahaman yang mendalam.

Dari pendalam terhadap kedua ayat tersebut ulama menghasilkan kompromi pemahaman dan keluar dari pertentangan makna. Ayat pertama mengandung arti bahwa interi yang kematian suami berhak tinggal di rumah almarhum bekas suaminya. Sambil menikmati hak tersebut setahun penuh, ia boleh saja kawin setelah melewati masa empat bulan sepuluh hari, yang dianggap sebagai masa iddah yang pasti. ${ }^{34}$

c. Mujmal

Secara etimologis mujmal berarti samar, atau majmu', (kumpulan), tidak terperinci. Sedangkan dalam istilah teknis ususl fiqh mujmal berarti lafaz yang maknanya tidak 
bisa ditangkap oleh nalar karena merupakan kata-kata yang secara kebahasaan bersifat tidak pasti atau pinjaman dari bahasa lain (bukan arab). ${ }^{35}$

Agak mirip dengan formulasi diatas tapi sedikit lebih jelas Abdul Wahab Kallaf menyumbangkan sebuah pengertian mujmal sebagai lafaz yang bila ditilik dari sigatnya tidak menunjukkan suatu pengertian, dan tidak ditemukan qarinah-qarinah dari lafaz lain atau keadaan yang bisa menjelaskannya. Kesamarannya berasal dari dalam diri lafaz sendiri, bukan merupakan faktor ekstern yang datang kemudian dari luar lafaz. ${ }^{36}$

Kedua definisi yang dikutip di atas hanya mengemukakan kesulitan pemaknaan terhadap lafaz mujmal, tanpa menjelaskan cara yang ditempuh dalam mencari solusi untuk kemudian menemukan maksud sesungguhnya dari lafaz-lafaz tersebut yang tidak boleh dianggap sepi, tanpa makna, hanya karena adanya kesulitan.

Definisi yang diajukan Bazdawi kelihatannya menjelaskan jalan keluar dari kesulitan itu, dimana bmendefinisikan mujmul sebagai lafaz yang memiliki banyak makna dan antara satu sama lain saling mirip. Maksud sebenarnya dari lafaz itu tidak akan diperoleh hanya dengan melihat ungkapan redaksionalnya, namun memerlukan sebuah penelitian, pencarian dan penelaahan.

Ada semacam jalan keluar memang terlihat pada rumusan itu, tapi sebaliknya definisi ini tidak tidak seperti definisi sebelumnya yang menjelaskan sebab adanya kesulitan pada lafaz mujmal.

As-Sarkhasi, agaknya mencoba menutupi kekurangan dari masing-masing pendapat sebelumnya. Beliau memberi rumusan mujmal sebagai lafaz yang tidak mungkin dipahami kecuali dengan meneliti lafaz yang berbentuk mujmal itu dan kemudian menjelaskannya. Itu dilakukan, terkadang karena asingnya sebuah kata yang dipinjam dari bahasa lain yang oleh pakar bahasa (Arab) disebut lugat garibah.

Melengkapi berbagai definisi yang telah dipaparkan, Muhammad Adib Salih membuat sebuah definisi yang tampaknya merupakan rangkuman dari beberapa definisi yanf dikutipnya pada Tafsir an-Nusus, yaitu lafaz yang redaksinya secara nyata adalah lafaz yang bermakna tersamar dan mengakibatkan maksud dari lafaz yang berbentuk mujmal itu, yang kemujmalannya terkadang karena terjadi transformasi makna dari yang zahir dalam bahasa (Arab) kepada makna khusus sesuai dengan kehendak syari', atau karena suatu lafaz mengandung banyak makna yang sama, dan terkadang pula karena lafaz tersebut memang merupakan kata-kata yang berasal dari bahasa asing. ${ }^{37}$ 
Untuk membedakan mujmal dengan musykil, lebih lanjut Muhammad Adib Salihmenyatakan bahwa tingkat ketersamaran mujmal jauh lebih tinggi dibanding musykil, sekalipun tingkat kesamarannya bersifat zati. Dan mengutip As-Sarkhasi beliau melanjutkan bahwa pada musykil maksud yang diinginkan sebenarnya sudah ada dan eksis pada lafaz, ia hanya membutuhkan tamyiz. Sedangkan pada mujmal maksudnya belum eksis pada sigat, yang ada hanyalah persangkaan terhadap maksudnya dengan penjelasan atau penafsiran. Adapun penjelasan itu sendiri bersifat eksternal, bukan merupakan bagia eintegral dari sigat. Kecuali bila pada lafaz mujmal terdapat makna yang digunakan secara praktis, maka maksudnya bisa ditangkap melalui cara tersebut, yaitu menganggap maksudnya adalah sebagaimana lazimnya kata-kata tersebut digunakan sehari-hari. ${ }^{38}$

Penjelasan di atas masih membuka peluang bagi nalar untuk memahami makna mujmal. Ini akan sangat berbeda dengan pendapat Wahbah az-Zuhaili yang menyatakan bahwa penjelasan mujmal berasal dari mutakallim bih (Allah dan RasulNya). Akal tidak mampu menjangkaunya sebagaimana pada mufassar. Berarti mujmal merupakan antonim dari mufassar. Mufassar dijelaskan langsung dari mujmil (yang menciptakan lafaz mujmal Allah. oleh antara lain Qadi abu Zaid ad-Dabusi dan sebagian pengikut Mu'tazilah. Al-Bazdawi telah memberitakan hal itu dengan pernyataannya bahwa hukum Zahir adalah tetapnya hukum yang diaturnya secara yaqin dan demikian juga halnya dengan nas, bahkan nas lebih utama ketika terjadi pertentangan antara keduanya.

Sementara itu sebagian ulama berpendapat bahwa hukum zahir dan demikian juga dengan nas, adalah wajib mengamalkan muatan hukum yang terkandung pada lafaznya, yang kewajibannya berstatus zahir (zanni, bukan qat'iy). Argument yang dikedepankan kelompok ini adanya ihtimal sebagaimana telah dijelaskan sebalumnya. Menutamakan nas ketika terjadi pertentangan zahir dan nas juga menunjukkan bahwa hukumnya tidak bernilai qat'iy. Ulama yang memegangi pendapat ini antara lain Syaikh Abu Mansur alMaturidy, Ahlul Hadis dan sebagian Mu'tazilah. ${ }^{39}$

d. Mutasyabih

Hukum lafaz mutasyabih adalah meyakini secara total bahwa maksud sesungguhnya ada pada syari' dan bersifat ilahi serta melakukan penyerahan sepenuhnya (taslim) kepada Allah tanpa berspekulasi dengan upaya mencari maksudnya.seorang hamba berkewajiban untuk menunjukkan totalitas keyakinan dirinya, dan menyerahkan 


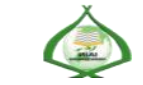

Volume 4 Nomor 2 Edisi Juli-Desember 2018

sepenuhnya pada teks yang eksplisit pada nas. Sikap seperti ini bahkan dianggap sebagai ukuran konsitensi seorang mukmin dan otensitas keyakinannya. Abu Zaid adDabusi menyetakan bahwa hukum lafaz mutasyabih adalah bertawaqquf (dependent), menyerahkan kepada Allah selamanya tentang maksud sesungguhnya kerana Allahlah yang maha tahu dan ini merupakan pendapat mayoritas ulama ketika mereka memahami maksud dari kalimat illallah.

\section{Penutup}

Mengistinbatkan hukum dari suatu lafaz nas didasari oleh pemahaman yang akurat terhadap nas dimaksud. Nas dapat berbentuk lafaz yang wadih, dan bisa juga dipresentasikan dalam bentuk mubham. Sepanjang dapat dipahami dengan jelas, suatu lafaz tidak membutuhkan penelaahan lebih lanjut, wajib untuk mengamalkan substansi lafaz yang dipahami secara mutabadar, dengan mudah ditangkap akal sehat. Kecuali bila lafaz tersebut telah ditakhsis atau dinaskh. Bila telah mencapat tingkatan muhkam, tidak ada peluang untuk memahami secara berbeda, wajib langsung diamalkan sesuai lafaz tersebut. Dan jika lafaz mengandung beberapa kemungkinan makna, perlu dilakukan penelusuran lebih lanjut secara serius untuk sampai pada suatu pemahaman yang lebih diyakini berdasarkan qarinah-qarinah tertentu. Dan untuk kategori lafaz mubham yang berada pada tingkatan mujmal dan mutasyabih, seorang mujtahid tidak diharapkan untuk memberi pengertian sendiri, dan mengistinbatkan hukum secara mandiri atas pemahamannya tersebut.

\section{DAFTAR PUSTAKA}

al-Bazdawi, Fakhr al-Islam 'Ali Ibn Muhammad ibn al-Husain, Kasyf al-Asrar 'ala Usul alFiqh, T.t.p: Maktab as-Sanayi', 1308 H.

al-Bukhari, Abd al-Aziz,. Kasyf al-Asrar Syarh Usul al-Bazdawi, T.t.p: Maktab as-Sanayi, $1307 \mathrm{H}$.

al-Khallaf, Abd al-Wahhab, Ilm al-Usul al-Fiqh, T.t.p: ad-Dar al-Kuwaitiyyah, 1968.

al-Khudari, Muhammad ibn Afifi al-Bajuri al-Masyhur bi asy-Syikh,. Usul al-Fiqh, Mesir: Matba'ahal-Jamaliyyah, $1329 \mathrm{H}$.

As-Sarkhasi, Abu Bakar Muhammad Ibn Ahmad Ibn Abi Sahl,. Usul as-Sarkhasi, Beirut: Dar al-Ma'rifah, $1382 \mathrm{H}$.

az-Zuhaili, Wahbah,. Usul al-Fiqh al-Islami, Damaskus: Dar al-Fikr, 1986.

Hasaballah, Ali,. Usul at-Tasyri al-Islami, Kairo: Dar al-Ma'arif, t.t. 
Salih, Muhammad Adib,. Tafsir an-Nusus fi al-Fiqh al-Islamiy, cet. 2, Beirut: al-Maktab alIslamiy.

Sya'ban, Zaki ad-Din,. Usul al-Fiqh al-Islami, Mesir: Tn.p 1968.

Syarifuddin, Amir,. Ushul Fiqh, Jakarta: Logos, 1999.

Zahrah, Muhammad Abu,. Usul al-Fiqh, Kairo: Dar al-Fikr al-Arabi, 1957.

End Note :

${ }^{1}$ Wahbah az-Zuhaili, Usul al-Fiqh al-Islami, (Damaskus: Dar al-Fikr, 1986), I: 717-728.

${ }^{2} \mathrm{I}$ bid, hlm. 312.

${ }^{3}$ Ibid.

${ }^{4}$ Abu Bakar Muhammad Ibn Ahmad Ibn Abi Sahl As-Sarkhasi, Usul as-Sarkhasi, (Beirut: Dar alMa'rifah, 1382 H), I: 163 Lihat juga Fakhr al-Islam 'Ali Ibn Muhammad ibn al-Husain al-Bazdawi, Kasyf alAsrar 'ala Usul al-Fiqh, (T.t.p: Maktab as-Sanayi', 1308H), I:46

${ }^{5}$ Abd al-Wahhab al-Khallaf, Ilm al-Usul al-Fiqh, (T.t.p: ad-Dar al-Kuwaitiyyah, 1968), hlm. 162.

${ }^{6}$ Zaki ad-Din Sya'ban, Usul al-Fiqh al-Islami, (Mesir: Tn.p 1968), hlm. 56.

${ }^{7}$ Muhammad ibn Afifi al-Bajuri al-Masyhur bi asy-Syikh al-Khudari, Usul al-Fiqh, (Mesir: Matba'ahalJamaliyyah, 1329 H), hlm. 132.

${ }^{8}$ Muhammad Abu Zahrah, Usul al-Fiqh, (Kairo: Dar al-Fikr al-Arabi, 1957),

${ }^{9}$ Ali Hasaballah, Usul at-Tasyri al-Islami, (Kairo: Dar al-Ma'arif, t.t), hlm. 265.

${ }^{10}$ Muhammad Adib Salih, Tafsir an-Nusus fi al-Fiqh al-Islamiy, cet. 2 (Beirut: al-Maktab al-Islamiy), I:143.

${ }^{11}$ Al-Baqarah (2): 275.

${ }^{12}$ Muhammad Adib Salih, op.cit., hlm. 148.

${ }^{13}$ Ad-Dabusi, op.cit, hlm. 201.

${ }^{14} \mathrm{Al}$-Bazdawi, op.cit, hlm. 46.

${ }^{15}$ As-Sarkhasi, op.cit, hlm. 164.

${ }^{16}$ Muhammad Adib Salih, op.cit., hlm. 165.

${ }^{17}$ As-Sarkhasi, op.cit. 165.

${ }^{18}$ At-Taubah (9): 36

${ }^{19}$ An-Nur (24):4

${ }^{20}$ Al-Hijr (15) : 30

${ }^{21}$ Muhammad Adib Salih, op.cit., hlm. 171.

${ }^{22}$ Abdul Wahhab Khallaf, op.cit, hlm. 168.

${ }^{23}$ As-Sarkhasi, loc.cit.

${ }^{24}$ Abd al-Aziz al-Bukhari, Kasyf al-Asrar Syarh Usul al-Bazdawi, (T.t.p: Maktab as-Sanayi, 1307 H), I: 51.

${ }^{25}$ Muhammad Adib Salih, op.cit I: 229

${ }^{26}$ Ad-Dabusi, op.cit. 204

${ }^{27}$ As-Sarkhasi, op.cit., hlm. 176

${ }^{28}$ Muhammad Adib Salih, op. cit, II: 253

${ }^{29}$ Amir Syarifuddin, Ushul Fiqh, (Jakarta: Logos, 1999), II:16

${ }^{30}$ Al-Baqarah (2): 228

${ }^{31}$ Ali Hasaballah, Usul at-Tasyri al-Islamy, (Kairo: Dar al-Ma'arif, tt.), hlm. 263

${ }^{32}$ Al-Baqarah (2): 240

${ }^{33} \mathrm{Al}$-Baqarah (2): 234

${ }^{34}$ Amir Syarifuddin, op. Cit., hlm. 19

${ }^{35}$ Muhammad Adib Salih, op.cit: 276

${ }^{36}$ Abdul Wahab Khallaf, op.cit., hlm. 173

${ }^{37}$ Muhammad Adib Salih, op.cit., hlm: 277-278

${ }^{38}$ Ibid.

${ }^{39}$ Ibid. 